\begin{tabular}{l}
$\begin{array}{c}\text { Yanbu Journal } \\
\text { of } \\
\text { Engineering } \\
\text { and Science }\end{array}$ \\
\hline ISSN: $1658-5321$
\end{tabular}$\quad$ Vol. 7, October $2013(1434 \mathrm{H})$

\title{
CORROSION INHIBITION OF ZINC METAL IN 4M HYDROCHLORIC ACID SOLUTION BY USING NAPROXEN DRUG (2-(6-METHOXYNAPHTHALEN-2-YL) ACETIC ACID) AS AN INHIBITOR
}

\author{
Emad Yousif ${ }^{1,2}$, Ali Al-Maamar ${ }^{1}$, Bashar Abdullah ${ }^{2}$ \\ 1Department of Chemistry, College of Science, Al-Nahrain University, Baghdad, Iraq \\ 2 School of Chemical Sciences and Food Technology, Faculty of Science and Technology, University Kebangsaan \\ Malaysia
}

\begin{abstract}
The inhibition of the corrosion of zinc in $4 \mathrm{M} \mathrm{HCl}$ by Naproxen has been investigated at room temperature using weight loss measurements. Results obtained showed that Naproxen is a good inhibitor and its inhibition efficiency (IE \%) increased with the increase of inhibitor concentration since it was $82 \%$.

The surface coverage was 0.82 at $300 \mathrm{ppm}$ inhibitor concentration, hence the optimum concentration was $300 \mathrm{ppm}$.
\end{abstract}

Keywords: Corrosion Inhibition,Zinc Metal, NaProxen Drug, HCI.

\section{INTRODUCTION}

Zinc is an active metal with numerous industrial applications and is mainly used for the corrosion protection of steel. The zinc coated steel materials provide a greater resistance to corrosion but when exposed to humid atmosphere, they undergo rapid corrosion with the formation of a corrosion product known as white rust[1]. The formation of white rust is generally observed in galvanized materials and renders the plated zinc materials unsuitable for industrial applications. Also, industrial processes such as scale removal and cleaning of zinc surfaces with acidic solutions expose zinc to corrosion. Therefore, in order to protect the metal from corrosion, the use of inhibitors is necessary [2].

To reduce corrosion must use corrosion inhibitor; a corrosion inhibitor is a chemical compound which is designed to protect a metal or alloy from corrosion. While corrosion inhibitors will not halt or completely prevent corrosion, they can reduce the rate at which corrosion occurs, and block early corrosion damage. A wide variety of chemicals can be used for this purpose, although many are toxic, and must therefore be used with care to protect the environment $[3,4]$.

Some drugs (such as ampicillin, ampiclox, cloxacillin, tetracycline, methocarbamol, aspirin, penicillin $G$, naproxen, etc)have been found to be good inhibitors for the corrosion of metal.

The choice of some drugs used as corrosion inhibitors is based on the following $[5,6]$ :

(a) Drug molecules contain oxygen, nitrogen and sulphur as active centres.

(b) drugs are reportedly environmentally friendly and important in biological reaction.

(c) drugs can be easily produced and purified. Naproxen belongs to a class of drugs called non steroidal anti inflammatory drugs. These drugs are used for the management of mild to 
moderate pain, fever, and inflammation. They work by reducing the levels of prostaglandins, chemicals that are responsible for pain, fever, and inflammation. Naproxen blocks the enzyme that makes prostaglandins (cyclo oxygenase), resulting in lower concentrations of prostaglandins. As a consequence, inflammation, pain and fever are reduced $[7,8]$.

The structure of naproxen is shown below:<smiles>COc1ccc2cc([C@@H](C)C(=O)O)ccc2c1</smiles>

\section{EXPERIMENTAL PART:}

Zinc strips of $\mathrm{BDH}$ grade was used in dimension $(8 \mathrm{~cm} * 2 \mathrm{~cm} * 0.5 \mathrm{~mm})$ (length, width, and thickness), scrubbed with emery paper, and washed with acetone several times, and a solution of $4 \mathrm{M} \mathrm{HCl}$ was prepared.

Naproxen inhibitor was prepared in $500 \mathrm{ppm}$ concentration, thereafter subsequent dilution was employed to prepare solutions 400, 300, 200 , and 100ppm.

Zinc strip was immersed in $4 \mathrm{M} \mathrm{HCl}$ solution in absence of inhibitor for specific periods of time and weighed in electronic balance after each period.

\section{Weight loss measurements:}

For weight loss measurements, the following formulae were employed

$\Delta \mathrm{m}=\left(\mathrm{m}_{1}-\mathrm{m}_{2}\right)$

Where $m_{1}$ and $m_{2}$ are the weights of metal before and after exposure to the corrosive solution, respectively.

The corrosion rate, the percentage of inhibition efficiency (IE \%) and the degree of surface coverage $(\theta)$ of the investigated compounds was calculated from the following equations [9].

Corrosion rate $=\Delta \mathrm{m} / \Delta \mathrm{t}$

IE $\%=\left[1-\left(\Delta \mathrm{m}_{\text {inh }} / \Delta \mathrm{m}_{\text {free }}\right)\right] \times 100$

$\theta=\left[1-\left(\Delta \mathrm{m}_{\text {inh }} / \Delta \mathrm{m}_{\text {free }}\right)\right]$
Where $\Delta \mathrm{m}$ free and $\Delta \mathrm{m}$ inh are the weight losses in the absence and presence of inhibitor, respectively.

\section{RESULTS AND DISCUSSION}

The corrosion of zinc strips in hydrochloric was studied by weight loss measurements using equations (1), (2), and the corrosion rates $(\mathrm{g} / \mathrm{min})$ of zinc were plotted against time (min) and as shown below in figure 1.

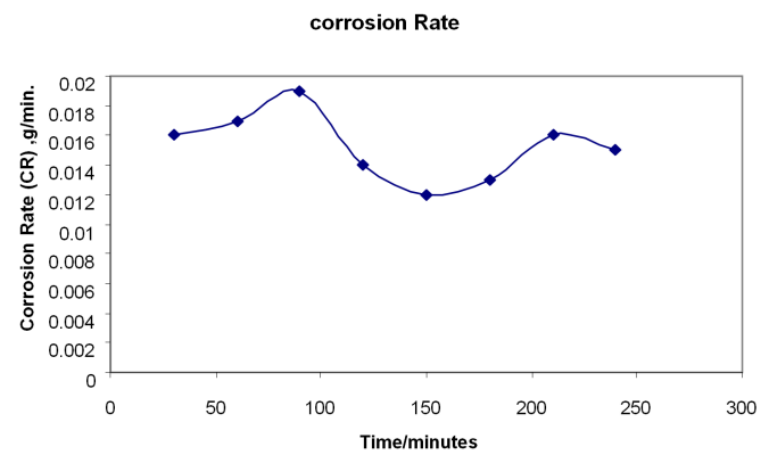

Fig.1. Corrosion rate versus immersion time for $\mathrm{Zn}$ strip in $4 \mathrm{M} \mathrm{HCl}$ without inhibitor at $25^{\circ} \mathrm{C}$.

The corrosion inhibitor is a chemical substance that interacts with the metal surface by an adsorption process protecting metal surface by forming film [10].

Inhibitor retards the corrosion either by reducing the movement or diffusion of ions to the metal surface, or by increasing the electrical resistance of metallic surface [11].

The inhibitor molecules could be adsorbed on the metal surface, so the aromatic nuclei and the oxygen atoms provides electrons that are needed to retard the formation of zinc ions, and the coating of zinc strips depends on how much the surface can accommodate the naproxen molecules, and the presence of this inhibitor induces chemical bonds with Zinc surface. These chemical bonds increased with increase of the inhibitor concentrations.

Figure 2 showed that the lowest corrosion rate was at $300 \mathrm{ppm}$, so it is the optimum concentration for inhibition, and this is might be attributed to the maximum coating of zinc strips at this concentration, and the naproxen molecules are distributed homogenously on 
the surface of zinc strips, and at 400 , and 500 ppm the accommodation of naproxen molecules on the surface of zinc strips might be relatively non-homogeneous.

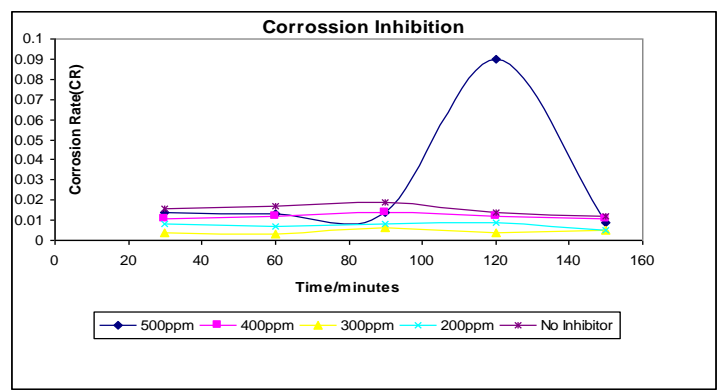

Fig.2. Corrosion rate versus time for $\mathrm{Zn}$ strip in $4 \mathrm{M} \mathrm{HCl}$ in presence of inhibitor at $(500,400,300$, and 200) ppm of inhibitor at $25^{\circ} \mathrm{C}$.

The surface coverage $\theta$, of the zinc strips by the adsorbed inhibitor was calculated from weight loss measurements using equation (3) shown in Figure 3.

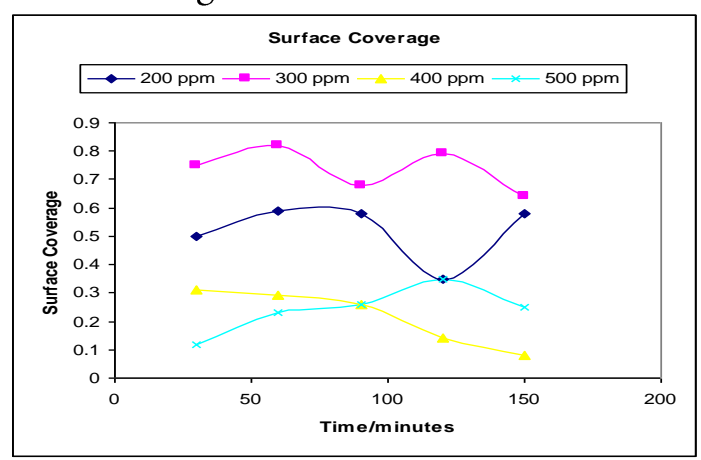

Fig.3. the surface coverage versus time at $25^{\circ} \mathrm{C}$.

The maximum surface coverage was found to be at $300 \mathrm{ppm}$, and this is could be attributed to the moderate concentration and the molecules of naproxen at this concentration diffuse from the bulk solution into the surface of zinc to cover it and inhibit the corrosion.

TABLE 1: THE VALUES OF INHIBITION EFFECIENCY(IE\%).

\begin{tabular}{|c|c|c|c|}
\hline $\begin{array}{c}\text { IE\%/500p } \\
\mathrm{pm}\end{array}$ & $\begin{array}{c}\text { IE\%/400p } \\
\mathrm{pm}\end{array}$ & $\begin{array}{c}\text { IE\%/300p } \\
\mathrm{pm}\end{array}$ & $\begin{array}{c}\mathrm{IE} \% / 200 \mathrm{p} \\
\mathrm{pm}\end{array}$ \\
\hline 12 & 31 & 75 & 50 \\
\hline 23 & 29 & 82 & 59 \\
\hline 26 & 26 & 68 & 58 \\
\hline 35 & 14 & 79 & 35 \\
\hline 25 & 8 & 64 & 58 \\
\hline
\end{tabular}

The inhibition efficiencies increased as inhibitor concentration increased, at $300 \mathrm{ppm}$ the inhibition efficiency was the maximum and it was $82 \%$ (Table 1). This behavior could be attributed to the increase of the number of adsorbed molecules at the metal surface.

\section{CONCLUSIONS}

The naproxen drug was used to inhibit the corrosion of zinc, and the inhibition efficiency was found to be maximum at $300 \mathrm{ppm}$ concentration of inhibitor.

The maximum surface coverage was found to be maximum at $300 \mathrm{ppm}$ inhibitor concentration which means that the maximum adsorption was at this concentration, and the molecules of naproxen drug have formed a thin film which prevents the penetration of acid into the surface of zinc.

\section{REFERENCES}

[1] Shylesha B.S., Venkatesha T.V., Praveen B.M., Salicylideneaniline as inhibitor for the corrosion of mild steel in $1.0 \mathrm{~N}$, hydrochloric acid, J. Chem. Pharm. Res., 4(7), 3414-3419, 2012.

[2] Odoemelam S. A., Ogoko E.C., Ita B. I., Eddy N. O., Inhibition of the Corrosion of Zinc in H2SO4 by 9- deoxy-9a- aza-9a- methyl-9ahomoerythromycin A (Azithromycin), Port. Electrochim. Acta, 27(1), 57-68, 2009.

[3] Shanbhag A. V., Venkatesha T V, Aprabhu R, Praveen B. M. , Inhibition effects of acetyl coumarines and thiazole derivatives on corrosion of zinc in acidic medium, Bull. Mater. Sci., 34(3), 571-576, 2011.

[4] Shah M.D., Patel A.S., Mudaliar G.V., Shah N.K, Schiff Bases of Triethylenetetramine as Corrosion Inhibitorsof Zinc in Hydrochloric Acid, Portugaliae Electrochimica Acta, 29(2), 101-113, 2011.

[5] Shah, M. D., Panchal, V.A.; Mudaliar, G.V.; Shah, N.K., Inhibitive effect of salicylidene-N-N'-dimorpholine towards corrosion of zinc in hydrochloric acid, AntiCorrosion Methods and Materials, 58(3), 125130, 2011. 
[6] Abdallah M. , Zaafarany I., Fouda A. S. , Abd El-Kader D., Inhibition of Zinc Corrosion by Some Benzaldehyde Derivatives in HClSolution,http://www.springerlink.com/conte nt/but26617k53087g3, 2012.

[7] Fouda A.S., Elewady G.Y. El-Haddad M.N., Corrosion inhibition of carbon steel in acidic solution using some azodyes, Canadian J. Sci. and Indust. Res., 2(1),1-19, 2011.

[8] Odoemelam S.A., Ogoko E.C., Ita B.I., Eddy N.O., Inhibition of the Corrosion of Zinc in $\mathrm{H} 2 \mathrm{SO} 4$ by 9-deoxy-9aaza-9a-methyl-9ahomoerythromycin A (Azithromycin), Portugaliae Electrochimica Acta 27(1), 57-68, 2009.

[9] Thomas S., Birbilis N., Venkatraman M. S., Cole I. S., Corrosion of Zinc as a Function of $\mathrm{pH}$, corrosion, 68(1), 123-128, 2012.

[10] Bockris J.M., Reddy A.N., modern electrochemistry, Plenum Press, New York, 1970.

[11] Magdalena Nunez, 'Prevention of Metal Corrosion: New Research', New York, 8-9, 2005. 
تثبيط تآكل معدن الخارصين في 4 مولاري من محلول حامض الهيدروكلوريك بأستخدام دواء النابروكسين (6)-2)

\author{
عماد يوسف 1‘2، علي المعمر 1، بشّار عبدالله2

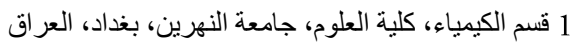

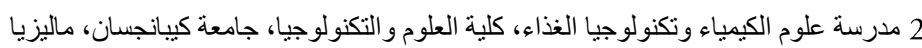

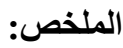

تم دراسة تثبط تآكل الخارصين في محلول 4 مولاري من حامض الهيدروكلوريك في درجة حرارة الغرفة بأستخدام دواء النابروكسين بطريقة النقص في الوزن. النتائج المستحصلة اثتتت ان دواء النابروكسين مثبط جيد حيث ان نسبة كفاءة التنبيط قد ازدادت بأزدياد التركيز للمثبط وكانت النسبة هي 82\%. كانت تغطية السطح حو الي 0.82 في تركيز 300 جزء من المليون ولهذا فأن التركيز الامثل للمثبط هو 300 جزء من المليون. 